$$
\begin{aligned}
& E 415 \\
& 9 \\
& 584 W 8 \\
& \text { copys }
\end{aligned}
$$


00118956746

HOLLINGER

pH 8.5

MILL RUN F3-1543 
E 415

.9 $584 W 8$

Copy 2

\section{THE ATTITUDE OF THADDEUS STEVENS TOWARD THE CONDUCT OF THE CIVIL WAR}

By

JAMES ALBERT WOODBURN

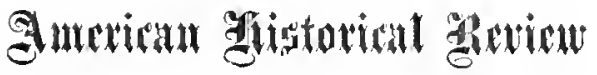


$E 11$

i)

$824 \div 8$

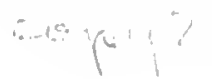

$\therefore:$ 


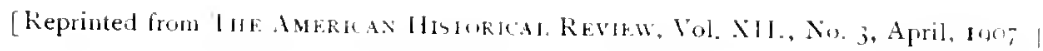

\section{THE ATIITUDE OF THADDELS STEVENS TOVARD THE CONDLCT OF THE CIVIL WAR}

From J11y, I86r, to his death in I860 Thaddens Stevens was the leader of the Reptulican majority of the House of Representatives. He was chairman of the Ways and Means Committee of the House throughont the war. and his attuntion was therefore largely devoted to questions of taxation and finance, of revenues and appropriations. These subjects in time of war offer a large field of study in connection with Stevens. Lith the purpose of this paper is not to consiler Stevens's contributions and services on these lines, but rather to bring into review his career and opinions in relation particularly to the more distinctly constitutional, political, and party issues which the war presented.

There are three salient aspects about which the political movements and controversies of the Civil War may best be organized and studied: first, the relation of the war to slavery; second, the relation of the war to the Constitution; third, the effect of the war upon the political status of the seceded states and their relation to the Federal Union. These, together with the increased war powers of the President, present the essential issues and plases of the struggle in which the student of war politics will be most concerned. I shall attempt to summarize or bring into brief review Stevens's record upon these salient feattres of the war.

Stevens recognized as clearly as any man then in public life the serionsness of the great conflict in which the conntry was engaged. and in the councils of the nation he constantly insisterl upon promptness, energy, and determination of purpose. To hin it was perfectly clear that the slavelolders were trying to destroy the Lninn to sare slavery; he would, therefore, destroy slavery to save the Lnion. The Sonthern states harl violated the Constitution to sain their independence: Stevens wotnd give them none of the benefits of the Constitution in the war that it was fond necessary to wase 11 m n then. These states had of their own free will repuliater the Constitution and withdrawn from the Lnion. Ile wonld no longer reconguize them as sister states under the alegis of law, but having mblued them as a belligerent enemy he would hold and govern them as conruered provinces. These principles of action he laid duwn in the 
lewinning, and in the pursuance of then he was clear, consistent. and undeviating from first to last. Firm of purpose and clear of vision. he had nomanner of doult as to the conrse the nation should fursue in the varying phases of the strugete for the Lnion. No one neel to have been left in doubt as to his policies and plans, for among the membership of the national thouse he stond pre-eminent as a man with the qualities that a public man most needs in such a time -danntless conrage, a conscience of his own, opinions of his own, and a will of his own. He encountered no superior in intellectual connht, and in the fight he was appointed to endure he well fulfilled the canous of the strontous same-he never flinched, he fouled no man, and he hit the line hard. In unconquerable fighter. he seemed made for a time of war, a time of storm and stress. and. his enemies themselves being the judges, le stomd foursquare to all the winds of opposition that came. These characteristics, together with the times in which he lived and the problems which he faced, make stevens one of the most menurahle figures in our Congresional anmals. I proceed to notice his war career with reference to the three aspects of the war to which I have referred-slavery, the Constitution, and the status of the states.

The evidence is conclusive that it was nut the original purpose of the nation in the Civil Mar to interfere with slavery. If it had been but a hundred days war, it would probalny have ended with slavery intact. Itostile intention aganst slavery was specifically disclaimed. Mr. Lincoln disclained it on behalf of the executive. and the two homses of Congress disclaimed it on behalf of the legislative brancly of the govermment.

It the beginning of the war, two days after the battle of Bull Kun. Congress passerl almost manimously, in hoth Houses, the famms Crittenden resolutions setting forth the objects of the war. These resolutions recited, in substance, that the war was not prosecuted for the purpose of sulujugating the Sonthern states-that is. uf resthrowing their state governments and reducing them to [rrvinces: nor for the purpose of interfering with slavery in the states, hut to defend and mantain the Constitution and the laws. and to preserve the L'nion with all the equality and rights of the several states umimpaired. The war should accomplish these ends and no more. This resolution voicel at the time the public opinion of the conntry, and almost the manimous opinion of the Republican party. President Lincoln represented this opinion, and in a conservative spirit he attempted at first to conduct the war without interfering with slavery, on the assumption that the status of the states and their relation to the Lnion had not changed. 
But the war nacle all the difference in the world. The events of but a few short months of war wrought a decided change in the purpose and temper of Congress and the conntry. It was seen that slavery was a sonrce of strength to the Rebellion. Conservative Lnion men were being rapidly and radically convinced that if the national govermment did not interfere with slavery slavery would serionsly interfere with the national government and the success of its arms. This change in policy and purpose is indicated by the fact that when the Thirty-seventh Congress came together again in its regular session in December, I86x, and an attenpt was made to reaffirm the Crittenden resolution which had received such nuiversal approval but a few montlis before, it was decisively rejected. It was rejected by a party vote mpon the motion of Stevens, who had thus considerable satisfaction in seeing that at least his own party had now come to his position in asserting its freelom from a doctrinaire impediment to the conduct of the war, and that the nation was now to feel free to strilic at slavery on to do whatever else wonld seem best calculated to promote the success of the national cause.

The events of the war hat, however, male no change in the purposes and opinions of Sterens. His principles were settled, his mind was fixed from the beginning. When the Crittenden resolution had been offered in July, he oljected to it and witheld his rote. He was one of fon in the llonse who were not realy to subscribe to its doctrine. He was onte of the more pronounced and radicalmay we not say more far-seeing? - antislavery men who believed that the Rebellion nust result in the destruction of slavery. He would not embarrass the governument nor prevent its dealing a blow in oprosition to slawery wh nocasinn should arise. He wanted the government to have a tree hand, an mnestricted liberty, in the conduct of the war, and he did not wish Congress to commit itself to a doctrine from which it would subsequently have to recede. He believed in the beginning what Lincoln canse to helieve in the midst of the war, that. in this national crisis. Congress and the President, representing the sovereign nation. hat the right to take "any step which miglit best subdue the eneny." the nation to indulge no seruples nor lay down any generalities that would interfere with the most vignous prosecution of the war.

Time clearly vindicated Stevens's leadership in this respect. A fortnight had not gone by after the pussage of the Crittenden resolution defining the objects of the war and giving an implierl promise that slavery would not be interfered with, before slavery had beconse a subject of sore discussion in Congress. It canse up in connection

Life and thriturgs of B. R. Curtis, I. 34 S. 
with the first Contiscation . Act, August 3. IS61. To this measure Sterens gave hin earnest snlport. This was the beginning of war legislation concerning slavery. It aronsed npmoition, because a sectim of the law required that muners shomk forfeit the slaves whom they allowel to be used in arms against the Lnited States or to labor in forts or intrenchments, or whom they shotrle employ in any naval on military capacity againet the national government.

In the delate an confiscation. Angust 2, I R6 I. Sterens roiced his deep oppositon to slavery and his purjose to strike at that insti-

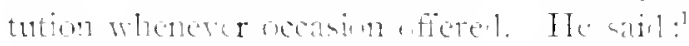

Goul forlind that I shound ever agree that the shaves should be returned th their maters and that you should rivet again the chains which you have once liroken. I do not say that this war is made for that [mirpace. Ink thue who male the war what its ohject is. Do not

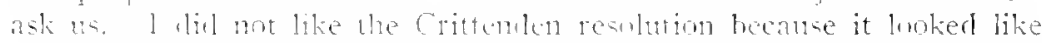

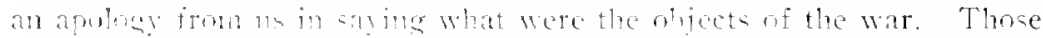

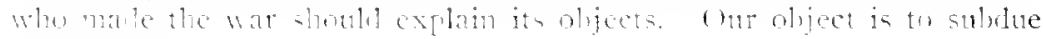
ilye reliel.

In this liscussion Sterens predicted the armine of the blacks and sain that he was realy to act ior it. "burifyng to gentionen as it may appers: that is my dretrine and it will be the doctrine of the white people of the North before two years moll round."

- After the rejection of the Crittenden resulution in Decenber, IS6r, Stevens wisher to luring his party and the administration to higher and more ageresuive sromel upon slasery and cmancipation. He would speak out the whole truth whether the nat on would hear or forbear. Con Decmler 3. Is6I, the first day of the regular session of the Thirty-seventl Congress, Stevens introduced a joint resolution, for cnactment into law. containing two propositions: the first was to strike for general emancipation as the best noms of crushing the Rebellion: the second, to make full payment for losses to loyal owners by this policy. His resolution asserted that slavery had cansed the Rebellion and that there conld be no peace and Union while that institution existed: as slaves are used by the rebels for supporting the war, and as by the law of nations it is right to liberate the slaves of an cnemy to weaken his power, therefore the President should be directed to declare free and to direct our generals in command to order freedom to all slaves who shall leave their masters or aid in quelling the Rebellion.

His speech of Jamury 22, I862, on these resolutions shows him

I In order to avoid excessive length of quotation. I have throughout this article omitted many sentences from stevens's speeches without sign of omission and have even in some cases used abridged phrases, without, I trust, ever misrepresenting in any degree his meaning. 


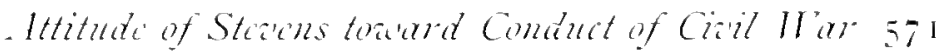

to be one of the earliest, boldest, most outspoken, and, I think, most influential of the antislavery advocates who were seeking to direct the war to antislavery ends. Stevens knew that Congress and his party were not pet ready to follow in the line of his proposals, and that the public sentinent of the country did not sustain his radical policy. But he wisled to educate that sentiment and to lead his party in the direction which he elearly saw would ultinately be found to be essential. He felt that the national government in the conduct of the war so far had becn weak, tinid, vacillating, ineffective, withont appreciation of the formidable task before it. The conntry needer a tonic: the administration neeled nerre and a stiffened syine. Stevens would infuse more energy into the prosecution of the war, and not be afraid to employ the means at hand. He did not think it a tine for honeyed words and conciliation. Te was not a representative of peace and good will; he was a representative for war: the business of war was to concuer, and in the war now forced upon the nation he stoor for firm, mulelding, uncompromising force. It seems reasonable to say that in energizing the war power of the nation and learling it to lay hold of every possible weapon for overcoming resistance to the national anthority there was in the national form no stronger personal force than Thadklets Sterens. A review of his speeches will give one a high appreciation of their educational influence in this direction.

He was bitter and unsparing in his denunciation of the Sonthern leaders for their course, and he songht to arouse the resentment and war spirit of the nation to crush the South. Fet he manifested a better conception of the Southern spirit and character and of the consequent nature of the task before the comntry than that possessed by his opponents and critics. Dismissing all hope of retnion by voluntary concession from the South, he wished to have it clearly. recognized, as it shoull have been, that from the Southern standpoint the separation was final, and that the Confederate States would consent to remion only through the exhanstion of war. Stevens saw that the task conld be accomplished only by the sacrifice of thonsands of lives and nuillions of money. He recognized that the Southerners were proud, haughty, obstinate, and that their training had led then to believe that they were born to command. They had declared that they would suffer their country to become a smoking ruin before they would submit. Stevens would accept the issue. He said:

It were better to bay wast the whole Sonth than to suffer the nation to be murdered. letter to depopulate the conntry and plant it with a new race of freemen, than to suffer rebellion to triumph. There should 
he no negotiation, no parly, no truce until every relel shall have laid cown lis arus and sulmitfal to the liovermment.

He was anong the first to see that this would not be clone until the Soutl was wholly exhausted:

I ed 15 not he leceived. Those who talk ahout peace in sixty days are shathow statesnew. The war will rot end until the Govermment shall more filly recondise the magnitude of the crisis: until they have diecoverel that this is an internecine war in which one party or the ullue must he rediced to hopeless fecloleness and the power of further efort shall be uterly amiliblated. It is a sad but true altermative. the Sonth can nerer he rended to that condition so long as the war in prosectutal on its prenent principles. The North with all its millions

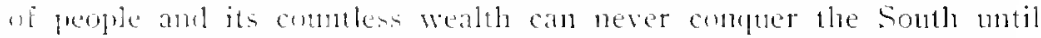
a new mole of warfare in aropted. So long as these states are left

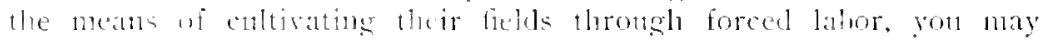

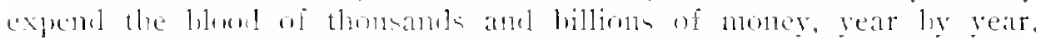

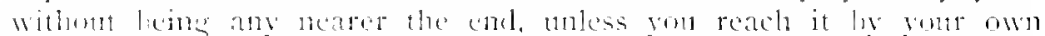
sulunssion and the run uf the nations. Slavery gives the Sontlo a

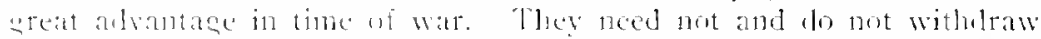
a single hand from the cultivation af the soil. Every alle forlied white man can le spared for the arms. The hack man, without lifting a weapon is the mainstay of the war.

Stevens would have no regarl for the "sympathizer with treason" who would "ritse an ontery alont a servile insurrection or prate learnelly abmut the Constitution." He thonght a " rebellion of blaves fighting for their freerom was not so abluorrent as a rebellion of frecumen fighting tom moler the nation." Ile wished the Northern armies to be " possessed and impelled hy the inspiration that comes

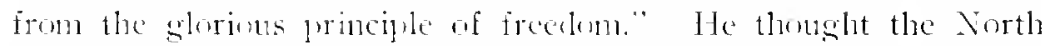
had not shown "the liery zeal that impelled the Sontly; nothing of that determinel and invincible courage that was inspired in the Kevolution ly the grand idea of liberty, equality and rights of man."

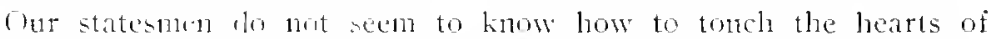
freenen and rouse them to battle. No snmul of universal liberty has gone forth from the calital. Ont generals have a sword in one hand and shachles in the other. I.et it le known that this government is fighting to corry at the great principles of the Declaration of Independence and the hluol of every freenan would boil with enthusiasm and his nerses le strengthened for a loly warlare. Give him the swotel in wne landul and the look of freclom in the other, and he will som sweep despotion and relielion from exery corner of this enntinent.

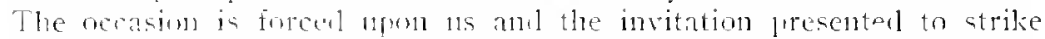
the chans from fun millons of human leings and create them then:

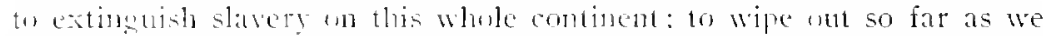

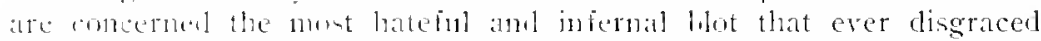

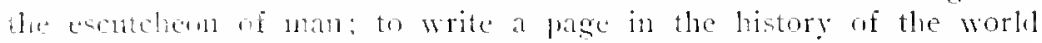
whec lutiglitues shall ecliphe all the records of heroes and sages."

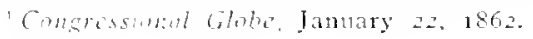

$=21+1$. 
This was effective uratory, the oratory of conviction and action. It was spoken at a time when slavery still scened rooted and grounded in the policy of the Fresident and of Congress and in the fublic sentiment of the conntry. Who will say that the voice of Stevens was not a powerful influence in loringing the country and its rulers to the higher plane of emancipation, to a readiness to direct the war for liberty as well as for muinn?

Is the war continued and the administration still seemed conservative and reluctant to pursue an antislavery phlicy, Stevens repeatedly expresscd his dissatisfaction. Lincoln's message proposing comprisated emancipation Stevens characterized as "the most diluted milk and water gruel proposition that was ever given to the American nation." He urged the passage of the Act (Narel 13 . I862) forbikling the return of fugitive slaves and he favored every act looking toward antislavery ents. He said he could not approve putting generals who sympathized with slavery at the head of our armies with orters to pursue and return fugitive slaves, nor did he like it to have our forces set to guard the property of rebel soldiers. When asked if he intended his charge against the I'resident and the Secretary of War or only against the generals in the field, he sair "I intend it shall alply where it belongs."

I an 110 sycophant, no prasite. What I think I say. These acts have been perpetrated without rebuke. Let the world determine where the responsibility rests. I helieve the President is as honest a man as there is in the worlu: but I helieve him to he too casy and amiable, and to he misled ly the malign influence of Kentucky comselors-and the Purcler State men.

He again urged the enlistment of negro troops and advised the administration not to be afraid of the cry of abolitionism, but to follow out the policy of military enancipation suggested hy General IIunter's oriler. Fle had no hope of success until that policy was adopted. He viewed the matter not mly as a question of emancipatiwn wallition, but as the only means of putting down the Rebelliun. For rebuking General Hunter he thonght the administration deserved to be driven out. and he denounced it for refusing the liberation and (moplyment of the slaves. He would seize all property of dislual men as onr amies artvanced, and he would plant the South with a military colony if the Southemers would not otherwise stlmit.

We come now to the attitule of Stevens toward the Constitution: the constitutionality of war measures; and the effect of secession and war on the status of the seceded states.

The antislavery policy advocated by Stevens and men like him

'Congressional Glohe. Iuly 5, 186z. 
was one of the aphlogies for party opmation to the war. The antislavery men were accused of wishos to make the war entirely subservient to alulition, and of being monilling to see the Lnion restored with slavery as it was. They woukl not be quiet but were abtruling their oning everyhere. with the resmit that while in Inly, Isfi, the nation wan muted, the Lnion furces were now divided. snce thome who wisherl to prosente the war solely for the purpose of restoring the [nion were alienated and estranged. ${ }^{1}$. I larse boly of conservative nen in the North. chiefly among those who har aprosed the kepullican party and Mr. Lincun's election. Hoked

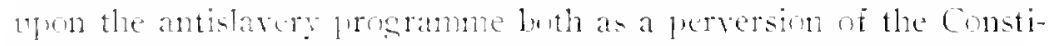
tution and a an entire kepartire from the original and legitimate - injects of the war. Lnder the leakrohip of allonit and able men. these conservative Democrats and Constitutional Lninists becane a compact party of onpostion whose opinions and purposes may be stmmarized ats follows:

(1) In the first place they aceptent the Grittenden resolution as their war platiorm. and they woukl have it clearly recognized that the primary and sile object of the war was to save the Lnion. It was not to interfere in any way with sasery. Any act or policy tenling to turn the military forces of the sorernment from mere mion-saring to alwlitionism, or toward emancipation as a means of unim-saving. was nneonstitutional, a perversion of the object of the war. and it onght to be resisted.

(2) In the second place the war must be so conducted and ended as to preserve the equality of the states. The Linion was based on this equality and it must be preserved. There must be no conquest or subjugation or interference with statehood or with the rights of the states, their governments, or their domestic laws. Whoever should attumpt by Ferleral authority to destroy any of the states, or trestablish territorial governments within them, was guilty of a high erime against the Constitution and the Lnion. The Lnion as it was must be restored and maintained under the Constitution as it is : and any person proposing peace on any other basis than the integrity of the states was as guilty a criminal as he who would propose peace on the basis of a dismenbered Lninn. The Southern states must not be reduced to provinces ne territories, nor the Southern people regarded as alien encmies; but the constitutional relation of the states to the Lnion was to be recognized as being undisturbed and the constitutional rights of the Southern people should be fully maintained. To prosecnte hostilities beyond these limits or in a spirit of

'Diven of New York. Congressional Globe, January 22, 1862. 
conquest would destroy state equality, subvert the Constitution, and prevent the Linion. ${ }^{1}$

(3) In the third plate a corollary to this view, the constitutional limits set to congressinal and executive power must be the same in war as in peace. Secession, rebellion, and war had made no change as to the power that Congress conld exercise within the states, be they the states of the Confederacy or the states of the Enion. The President's powers were not increased. Therefore lis executive orders. his proclamations, his military emancipation, his suspension of habcas corpus, his arbitrary arrests, must all be tested by the terms and canons of the Constitution as in times of peace. "The Lnim as it was: the Constitution as it is," was the maxim of the party.

In the riew of these constitutionalists, the Lnion was to be saved only by, through, and under the Constitution-nothing more nor less. They ilealized the Constitution. To them the Constitution was identical with the nation. Without it there could be no Lnion. The Constitution gone, the republic is dead. The war was for the preservation of the Constitution and for that alone; it was against the Constitution and because it was binding on all that the Southerners were rebels. These conservatives denounced the antislavery adrocates as being indifferent as to whether or not their policies were in harmony with the Constitution, and this fact made the hated abolitionists-as they called all antislavery men-as guilty criminals as the secessionists themselves.

In the view of this party almost everything that the President or Congress proposed or did, for the effective and vigorous prosecution of the war. was unconstitutional. Confiscation of slave property was unconstitutional; retaining fugitive slaves within our lines was unconstitutional: the military emancipation of Fremont and Hunter was uneonstitutional; the use of slaves as contraband was unconstitutional; Lincoln's plan of compensated enancipation was unconstitutional; enlistnent of negro troops was unconstitutional; the Emancipation Proclanation was unconstitutional; the draft was unconstitutional; the suspension of the writ of habcas corpus was unconstitutional; military arrests were unconstitutional; suspending or in any way reinstituting state govermments at the South was w11constitutional; Lincoln's appointment of military governors and his beginnings of reconstruction were unconstitutional. No exercise of power was constitutional except what was unmistakal)ly granted by a strict construction of the Constitution interpreted as in times of peace. Instead of the war's having made all the difference in the

\footnotetext{
'Pendleton's resolutions, Congressional Globe. Iuly $3 \mathrm{I}, 186 \mathrm{I}$.
} 


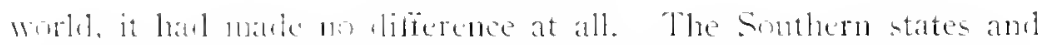

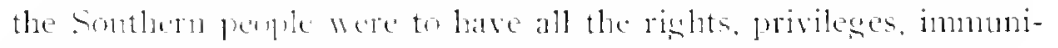
ties. and hemethe if the comstitution. They were not lunnd by its

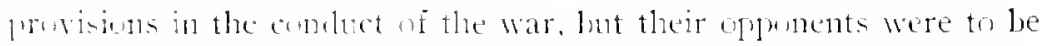
restraned from exery asseressive act of pmer mot within its specific linits. This was a iearinl hambicap for the national gevernment. such a polieg wothl have led in a pasmive and harmless war-ahonst

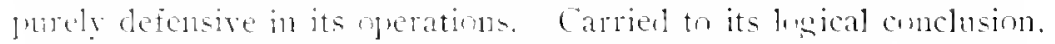
no invasion of the Sonthern states ures subluing of the Southern freple would have leen pusible under it, and it is very problematical whether the Constitution and the Lnim condr have been saved for the South muler its operation.

To this party am its constitutional view Thadruns Stevens was chanetrically oppred. Ite was its coustant and stout antagnnist. He leribled these sticliters for the Constitution and in unsparing terms he demenmed all their works and wass. They and he were

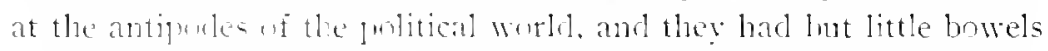
of mercy for one another. Stevens wisher to estatlislu a lesal basis for the conduct of the war that wotkl give the nation a chance to fight, and in the first riscussion on slavery and the war to which I have refured (Angust 2, I.86I) he laid down the legal and proper prenises for that fight. He brusher theories aside. lonked at the facts, and saw things as they were, and he songht a basis of action best calculated to hring the resuit desired. He took the bold ground that in the contest for its life the nation was not bound by the limitations of the Constitntion. The war harl abrogated the Constitution -unt where it was respected and conk be enfored by orelinary civil processes, hut with respect to hostile conferlerated states that had rejeeted and repuliated the Comstitution, trampled it under foot, and were resisting its restoration by orsmized armies. The people of the Confederate States were fublic lelligerent enemies, and the nation in its effort to nerome them was brum only by the laws of war and the law of mations. The Comstitution harl no right to intervene if it strod in the way of the laws of war in dealing with the enenzy.

Who say the cinstitution nuns come in in har of omr action? It is the advocates of rebels, of refels who have repmliated the Constitution, who have somsht to werthrm it and trample it in the dust. Sir, these relel who have linegarded and set at defince that instrument are ly every rule of municipal and international haw, estupped from plealling it agamst onr action. Sir, it is an alsurdity. There must be a party in court to plean it, and that party to he entitled to plead it in court. munt first acknowledge its supremacy, or he has no business 
to be in court at all. . They can not be permitted to come in here and tell us that we must he loyal to the Constitution. ${ }^{1}$

When he was asked how members of Congress who had taken an oath to support the Constitution could violate it in their action. whether rebels complain of it or not, he replierl that they do not violate it when they are operating against men who have no rights to the benefits of the Constitution. The law of nations was plain upon this point, the law established in the rlays of Cicero. "Inter arma silent leges." "This is a law that has been in force to the present time, and any nation that disregards the law is a poor pusitlanimons nation which subnits its neck to be struck off by the enemy:"

Stevens arlmitted that the Constitution, while it was in force for the South, did not authorize Congress to interfere with slavery in the states. While the Constitution and laws were supreme no nne woukl attempt it. Fut when the Constitution had been repudiated and set at refiance by armed rebellion the case was different.

There were not [he sail] three thothand aholitionists, properly so callest in the Eniterl States. Before this war the parties were bound together hy a compact, hy a reaty. called a Constitution. They admitted the valulity of municipal laws hinding on each. This war has eut asmder all these ligaments, ahrogated all these olligations. Since these States have voluntarily thrown ofi that protection and placed themselves under the law of nations, it is not only our right but our duty to knock off every shackle from every limb.

He who wishes to re-establish the Union as it was cannot escape the guilt of attempting to enslave his fellow-men. The "Union as it was and the Constitution as it is", is an atrocions idea; it is man-steal. ing. The Southern States have forfeited all rights under the Constitution which they have renounced. They are forever estopped from chaining the Constitution as it was. The Cniterl States may give them those rights if it choose, hut they cannot raim them. If a disgraceful peace were mate leaving the catse of this rebellion and the cause of future wars untouched and living, its authors would he the objects of the deepest execration and of the hackest infany. . . All this clamor against ralicals, all this cry of the "Union as it was", is but a persistent effort to re-estahlish slavery and to rivet anew forever the chains of bondage on the limlss of immortal beings. Nay the God of Instice thwart their designs and paralyze their wicked efforts."

Stevens believed that in an energency in order to "snateh the nation from the jaws of leath" Congress was anthorized to declare a dictator. It was a fearful power, and he hoped the necessity for it wonld never arise. Fint the safety of the preople is the supreme

\footnotetext{
${ }^{1}$ Congressional Globe. August 2, 1861.

2 Thid., January 22. Isi6.4.
} 
law, and rather than see the nation perish, rather than see it dishonore] by conpronise, concession, and sumission, rather than see the Linom disserercil, he was realy to apply the dictator's power.

It will be seen that Stevenc's constitutimal position, or extratcontitutional pusitum, was consistent, strightionwart, and out-

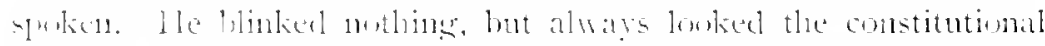

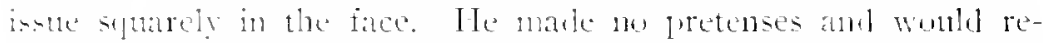

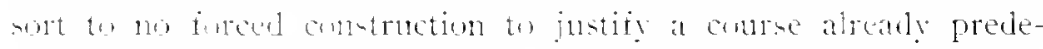
terminesl. This is sech still more chearly in his attitule toward

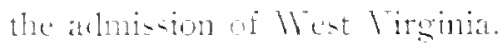

The Cim-itution clearly proviles that no state shall be divided

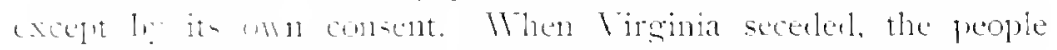

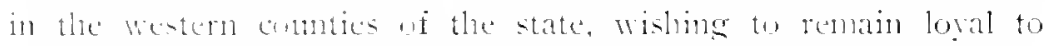
the lonum, astment to form at state gorernment and choose state uffece and a sate legislature. They elected Senators aml Representatives to finglens, who wete almitted th their seats. They clamed to be the jerple of birgina, constitutionally competent to give it a con-ent the the fimmation of a new state within the borlers of the (het lominim. This pelple having given its comsent the the divion of the ohl state of Virania, immeliately erected itself into the new state of IV Vest Viramia. Vobmly consented exctit those within the limits of the new state. That is the new state consented to the division of the ald. And when the new state hat hew ahluittel acording to preatrangement. Mr. Pierpont, pretenting tw the the covernor of the state that pretended to be Virginit, was to move over to Alexandria and keep up the pretense of being the gubermatorial head of old Virginia, with an official broly that Sunnere afterwarl called the "common councit of Alexaniria." As Sterens sail after the war, "all the archives, property, and effects of the Pierpunt Govermment were taken to Richmond in an ambulance." This was the government recognized during the war as the legitinate constitutional govermment of Vircinia.

There were distinguished nembers of Congress who sought to find around in the constitution, or in the fictitions construction af that instrument, for this process by which Virginia was diviled and West Virginia admitted. It was not the way of Thadrleus stevens. To Stevens the procedlings, of the argunents based upon them, were all ridiculous and absurd. He was opposed to giving seats in the House to nembers from Virginia after the secession of that state. for "We know," as he said, " that members have been elected th this llonse by only twenty wites and thoue 
cast muler the suns of a furt. Now, to say that those gentiennen represent any district is a mere mockery."

Stevens was willing to acomplish the end in riew, the disnemleernent of Virginia and the almis-ion of the new state. the suffieient pround for the act leeing that it would weaken the eneny and help the national canse. But he recognizerl that the legal ground for the proceeding was, not the Conntitution. but the laws of war. "Te may admit West Virginia," he sail, " not by any provisions of the constitution but nuler our absolute power which the laws of war sire us. I shall rote for this bill upon that thenry and that alone: fer 1 will not stultify nyself by supposing that we have any warrant in the Constitution for this proceeling."

He regarted it as nockery to claim that the legislature of Virsinia han ever consented th the division of that state. The majority of the people of Virginia. organized as a political communuty, was the state of Tirginia. That state had changed its constitution and its relation to the foleral govennment from that of one of its nnembers to that of secession. The act was treason. but so far as the state corporation was concemed it was a ralid act and governed the state. "A small number of the citizens of Virginia-the people in West Tirginia-assumbled together, disapproved of the acts of Jirginia and with the utmost self-complacency called themselves. Virginia. Is it not ridiculous?"

That scens more straightforwari than to stretch the Constitution by a forced and fictitious construction while claining to respect its frovisions. To a laynan it secms like better law, sonnder sense, and more correct pulitical science. if the United States was to he regarded as a nation and not a mere congeries of states.

This view of the character of the state and the effect of secession he maintained consistenty on all occasions. He looked upon the Sonthern states as public enemies. We were at war with an acknowlelged belligerent, with a foreign nation, and since such a war had annulled all former compacts existing between them neither could clain as against the other the aid of the Constitution. Stevens held that the Southern states, having comnitted treason, renounced their allegiance to the Union, discarded its Constitution and laws. organized a distinet and hostile govermment, and by force of arms having risen from the condition of insurgents to the position of an inclependent power de fucto. and having been acknowledged as a helligerent both by foreign nations and by our own government, the Constitution and laws of the Lnion were set asicle as far as they were concerned, am that as hetween the two belligerents they" were under

${ }^{1}$ Congressional Globe. December 2. I86. 
the haw of war and nations alone. If the redel states were still in the Lnion and under the Constitution, as some contended, he saw m reason why they should not elect the next President of the Cnited states. If the rebels tecindel (1) rote, then one lundred loyal nuen who, as his legal opponents contenuled. still continued to be "the state." night meet and choose clectors. The few loyal men around Fortress Nonroe or Norfolk, or Alexandria, and a few cleansed patches in Lnuisiana, being one thousandth part of the state, might clonse lectors for the whole state. It was such reasoning that semed like a mochery of comstitutional law and political science to Stevens.

Is to the minority who were loyal to the Lnion within a seceded state. he would regard them as citizens of that state and subject to its comelitions. They must migrate or hear the burdens and penalties uf their lomicite, although in dealing with persons he would distinguish hetween the inmoent and the guilty. The states were at war with the nation. The iwea that a few loyal citizens are the state and may override and goven the disloyal millions, he was malhte to comprehend. "If ten men fit to save Sodom can elect a sovernor and other state officers against more than a million Sodomites in Virginia, then the democratic doctrine that the majority shall rule is discarded and ignored."

The position of Stevens was vigrorously assailed by Mr. Francis I. Rlair, of Nisontri, in a moble specth in the Honse, February 5. ISif. Blair held that Stevens's policy of confiscation could only be affected by the extermination of nu whele kindred race in the South. The worlil would expet them to shed the last Irop of blood rather than to submit to such spriation, with mo alternative but to die as paupers. Europe would be justified in intervening to put down such an mnovation on the corle of hmmanity and to arrest barbarities in lefince of the law of nations. It was frenzied altruism tending to promote " amalganation of repugnant races in the name and by the charm of equality."

Blair held that the Southern states were indestructible; that their status was like that of Missouri. Whose state organization had remained loyal to the Lnion. All that was needed was to drive out the rebel power that was holding the state government in duress. ( nur army and navy were erushing the life ont of the usurpation, retoing what Blair called the "assumption of Stevens that the state govermments in the rebel states are as perfect now as before the rebellion, and being subsisting states. capable of corporate action, they have as states changed their allegiance from the Lnited States to the Conferlerate States." In this uncleniable fact, as Stevens lad 
Stated it. J3air maintained that the secession doctrine was "absolutely recognized, with more listinctness than Calhoun ventured to urge it."

llere the majority of dislogalints in a state [said Brair] have the right almitted to over-ricle a minority of loval men and make them forswear their alleginnce to the L'nion. No man. North or South, ever assertul the secestion cathe so hollly in the form as the gemtlenan from Pennsylvania. He founds the relel govermment upon the will wi it majnrity of the people: proclaims that the minority, thongh loya! w, the Gencral Government (which has a right to the allegiance if all) mons al awdum the states of subcrile to their authority: insists that the usurgation has established indegemlent states endowed with all the immmities and riglus of an independent nation carrying on a legitinate war. This is the sccessinn. abolition, alsulute-conquest doctrine which the gentlemin has lomached in defiance of mational and State Conctitntims, the law of the civilized world and of all humbunity.

On May 2, Isfit, during the discussion in the Ilouse on the Warle-Daris plan of reonntruction, Stevens had nccasion to refer to these criticisns. Ile rentated his position that the Soutl was only a leelligerent, with such rights only as the laws of war might accord. The fact of their leeing rulets as well as belligerents put them in a wore predicarent and mily extended our rights and justified the stmmmum jus of martial law. In urging again a general scheme of contication he sail the comntry shomld decile whether this was an unjust war, and whether the enemy was whtinate and ought to bear the burden of the war.

Stevens pictured in rigurous language the suffering and destruction of the war, which he denomeer as unjust and as deserving of punishment. "If we are nut justified". he said. "in exacting the extrence demands of war then I can hardly conceive a case where it would be applicalle. To allow then to return with their estates untouched, on the theory that they have nerer gone ont of the Lnion. secms to me rank injustice to loyal men."

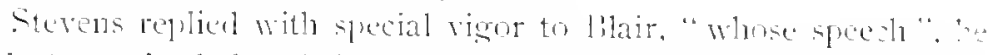
saiil, "contained the distilled virus of the copperhearl." Ite recognized that selling cotates in perpetuity as the result of attainder for treas m was forbiflen by the Constitution: conviction for treason could wrk no such comserplence. What he contended for was the

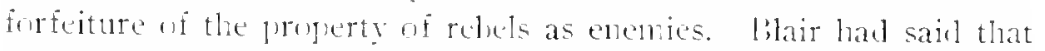
Stevens harl "treated with serm the inlea that States held in duress by the relet poner lave a right to look to our laws and Constitution for protection." Stevens replied:

This is a false statement of my pustions. If the armies of the Confederate states should werm a loyal state and hold it in duress.

'C'mgressunal Glohe. Fehruary 5. 1864. 
that state whlul hase a righlat we alpeal to the Constitution for protecthim. But a state which ly a free majurity of its voters has thrown Ifif it allegiance the the constitution and hulds itself in cluress ly its

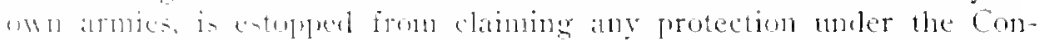
stiturions. To way that steh a state is within the pale of the Lnion 6 an to chain protection muller its conctitution and laws is lut the raving of a maklmatr.

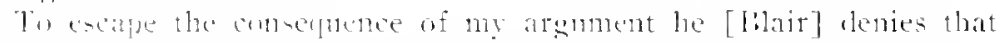

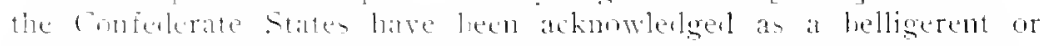

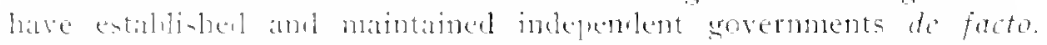

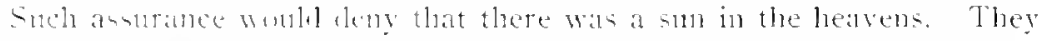
hatre a comgres in which elevers states are reprencoted: they have at leat 3 mone soluters in the field: their prickets are almont within sight of IVahington. They have shigs of war on the nean hestroying

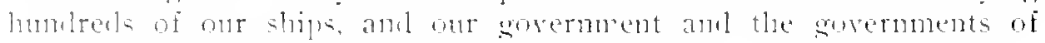

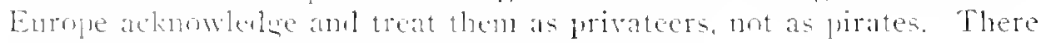

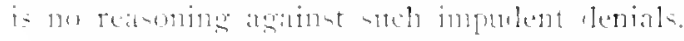

sterens dented that he was combenancing secension in recong-

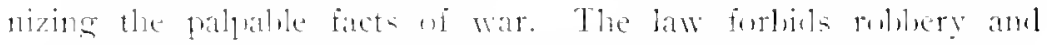
murter. Tut these eringes exist de facte. Dhes the man who declares

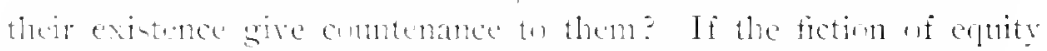

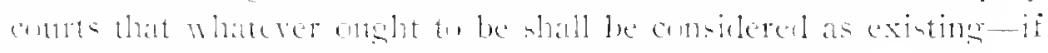
this is true, then the relet states are in the Lnim.

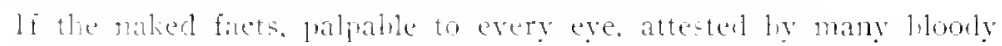
battle-fieds and recorled he every day hostile legiatan hoth in

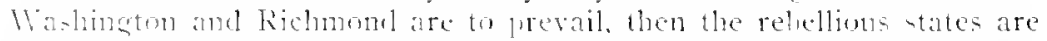
no nowe in the Lninn in fait, than the lowal states are in the Confederate States. Xor shminl they ever le treated so until they repent and are relsaptized into the National L'nion.

Stevens congratulated the country that the House had recently

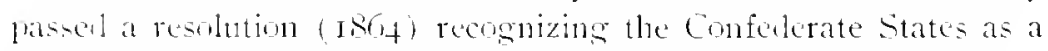
public encmy. That was the doctrine for which he had been contonding. The conserpucues which he hal sought to establish would follow as a corollary. "I have lived", he said, " to see the triumph of principles wheh. although I had full faith in their ultimate success. l dill not expect to wituess. If Providence will spare me a little longer. until this government shall be so reconstructed that the fowt of a slave can nerer again tread upm the soil of the Republic, I shall be content to accelt any lest which may await me."

Thene extracts will serve to make clear Stevens's attitude toward the chief instes of the Civil War. Those whom he opposed will not be easily reconciled to bonor his memory. Is Sumner said. " To one gave to language a sharper hite." His words were words of areasm, satire, denunciation. They arinsed resentment and often left a bitur sting. llis antagmints dreaded him. and he has been

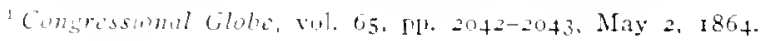


spoken of as a man of hate and vindictive vengeance. Put there is testimony to show, from party friend and fore alike, that he was a man of deep and tencle. humanitarian feelings. Ito desired fair play and a square deal for all mankind. The punitive measures which he favored did not spring from personal fuelings. It was the cause that he hated or imeel. He hover justice: he entertained a deep hatrel of slavery and secession. and he believed that a just punishment, as well as nerey, should be visiterl unom those whom he considered as the suilty authers of his combers wes. In this he was but human, a natural man legotten of passinnate times, anrl he molably represented to a large legree the feelings of a majority of his fellow-comtrymen. He dephed the compmomising errors of the fathers, and his ereat fmpose wats of write the ha he justice and human erpulity into the Constitution of his conntry; and he would feign no fraternal, sentinental regard for those who, as he thought, sought to violate, obstruct, or pervert these great principles of gorerument.

James Albert WunEURn. 
. 


